\title{
Evaluation of Testicular Toxicity and Sperm Morphology in Rats Treated with Methyl Methanesulphonate (MMS)
}

\author{
Kazuya KURIYAMA ${ }^{1)}$, Tsuyoshi KITAMURA ${ }^{1)}$, Ryohei YOKOI ${ }^{1)}$, \\ Morimichi HAYASHI ${ }^{1}$, , Kazuo KOBAYASHI ${ }^{1}$, Junji KURODA ${ }^{1)}$ and \\ Hirotada TSUJII2)
}

1)Toxicology Research Laboratories, Kissei Pharmaceutical Co., Ltd., 2320-1 Maki, Hotaka, Minamiazumi, Nagano 399-8305, ${ }^{2)}$ Faculty of Agriculture, Shinshu University, 8304

Minamiminowa, Kamiina, Nagano 399-4598, Japan

\begin{abstract}
Methyl methanesulphonate (MMS), a potent alkylating agent and testicular toxicant, was orally administered to rats for 5 days at $40 \mathrm{mg} / \mathrm{kg}$. During the recovery period of up to 5 weeks, males were evaluated for testicular toxicity and sperm morphology. The 5-week recovery period were designated as follows: Day 1 (the day after final treatment); Week 1, Week 2, Week 3, Week 4 and Week 5 (1, 2, 3, 4 and 5 weeks after final treatment). Morphologically abnormal sperm increased beginning in Week 3, peaked in Week 4 and declined slightly in Week 5. Histopathological examinations indicated retention of step 19 spermatids at stage IX from Day 1 through Week 3. Quantitative evaluation of spermatogenic cells indicated a decrease in the number of late pachytene spermatocytes and early spermatids on Day 1. TUNEL examination showed a significantly high frequency of apoptosis in the meiosis cells in Week 1. In the present study, genetic damage induced by treatment with MMS affected spermatogenesis and a wide variety of spermatogenic cells in the testis. Apoptosis in the course of meiosis seemed to be involved in the elimination process of genetically insulted germ cells, and this process seems to play an important role in eliminating and/or decreasing the germ cells with retention of spermatids and the potential to express morphologically abnormal spermatozoa.
\end{abstract}

Key words: MMS, Rat, Spermatogenesis, Apoptosis, Sperm morphology

(J. Reprod. Dev. 51: 657-667, 2005)

f n ICH guideline (Step 4, 29 November 1995, amended in November 2000) recommends histopathological examination of the testis as the most sensitive method for the detection of drug effects on spermatogenesis and fertility. It also recommends sperm analysis including sperm morphology as an optional procedure for confirmation or better characterization of the observed toxicity, such as pathological changes or

Accepted for publication: January 20, 2005

Published online: July 21, 2005

Correspondence: K. Kuriyama

(e-mail: kuriyama@kisseiamerica.com ) decreased fertility. In this regard, increased knowledge of the morphological alterations in sperm shape and their relation to the histopathological findings is desirable.

In the present study, methyl methanesulphonate (MMS) was selected as a compound expected to exhibit sperm morphological alterations in the epididymis. MMS is a potent alkylating agent, which is known to be a testicular toxicant. MMS caused a decrease in testes and epididymes weight, a decrease of germ cells, exfoliation of germ cells and vacuolar degeneration of Sertoli cells after oral treatment of $40 \mathrm{mg} / \mathrm{kg}$ for 2 weeks, and induced 
morphologically abnormal sperm heads after a single oral administration of $100 \mathrm{mg} / \mathrm{kg}$ in rats [1, 2]. MMS is known to induce morphologically abnormal sperm after 5 days of exposure in mice [3]. One of the causes of the induction of morphologically abnormal spermatozoa is thought to be alteration of germ cell DNA. Lesions in germ cell DNA increase in severity throughout the maturation in the reproductive tract and disrupt the differentiation of spermatozoa [4,5]. However, there is little information regarding the morphological alterations in sperm shape and their relation to histopathological findings.

In the present study, rats, the most common laboratory animal used for the evaluation of toxicology studies in drug development, were orally treated with MMS for 5 consecutive days, and sperm examinations and histopathological examinations were performed over 5 weeks of the recovery period.

\section{Materials and Methods}

\section{Animals and treatment}

All animal experiments were carried out in accordance with the Guide for the Care and Use of Experimental animals of the Toxicology Research Lab., Kissei Pharmaceutical Co., Ltd. Crj:CD(SD), SPF rats, 8- to 9-week-old males were purchased from Charles River Japan, Inc. (Kanagawa, Japan). The animals were kept in a barrier system where the temperature $(22.6$ to $27.7 \mathrm{C})$, the relative humidity (45.6 to $65.0 \%$ ), the ventilation $(12.21$ times/hr) and illumination cycle (12hr light/12hr dark) were controlled. The animals were allowed free access to tap water and pellet diet (CE-2, CLEA Japan, Inc., Tokyo, Japan) throughout the quarantine, acclimation and study periods. The quarantine and acclimation period was set as 9 days and all the animals were 10 to 11 weeks old at the start of treatment.

\section{Chemical}

Methyl methanesulphonate (MMS, 99.9\%, Aldrich Chemical Co., Inc., Milwaukee, WI, USA) was dissolved in distilled water (JP grade, Otsuka Pharmaceutical Industries, Tokushima, Japan). MMS was prepared freshly each day.

\section{Experimental design}

The male rats were treated with MMS $(40 \mathrm{mg} / \mathrm{kg}$, p.o., $5 \mathrm{~mL} / \mathrm{kg}$ body weight) once daily for 5 consecutive days. Control males received distilled water in the same regimen as the MMS-treated group. In the recovery period, on the day after final administration (Day 1), 1, 2, 3, 4 and 5 weeks after the final administration (Week 1, Week 2, Week 3, Week 4 and Week 5), 5 animals from both the control and MMS-treatment groups were sacrificed for sperm examination in the cauda epididymis. An additional 5 animals from both the control and MMS-treatment groups were prepared for precise histopathological examination of the testis with quantitative evaluation of spermatogenic cells and TUNEL examination.

\section{Necropsy}

All the male animals were sacrificed by inhalation of carbon dioxide, examined for gross abnormalities and their testes and epididymides were weighed individually. The right cauda epididymis was employed for sperm morphological examination and the caudal epididymal sperm count. The right testis and epididymis were fixed in formalin acetic acid (FA) solution for 5 days before final fixation in $10 \%$ buffered formalin [6].

\section{Histopathology}

Fixed testis and epididymis were embedded in paraffin, sectioned at approximately 4 to 5 microns thickness, and stained with hematoxylin and eosin (HE), or periodic acid-Schiff (PAS). The severity of histopathological findings were graded as follows: no significant change (-); very slight change $( \pm)$, $<5 \%$ seminiferous tubules or epididymal ducts; slight change (+), 6-20\% seminiferous tubules or epididymal ducts; moderate change (++), $21-50 \%$ seminiferous tubules or epididymal ducts; and severe change $(+++),>50 \%$ seminiferous tubules or epididymal ducts.

To detect the direct effect of MMS on germ cells, quantitative evaluation of spermatogenic cells in seminiferous tubules was performed on Day 1 and Week 1 slides with a simplified morphological method [7]. Four seminiferous tubules per animal exhibiting round shape were randomly selected for four spermatogenic stages (Stages II-III, V, VII, and XII), and the numbers of seminiferous epithelia were counted in each tubule. The cell types 
distinguished here were spermatogonea, preleptotene spermatocytes, zygotene spermatocytes, pachytene spermatocytes, round spermatids, and Sertoli cells. The ratios of each type of spermatogenic cell to Sertoli cell per seminiferous tubule cross-section were calculated as measures of the population of germ cells. Sectioned samples on Day 1 and Week 1 were also labeled with TUNEL solution (ApopTag Peroxidase Kit; Oncor Appligene, Basel, Switzerland) to detect cells undergoing apoptosis. TUNEL positive cells per Sertoli cells were counted in 5 seminiferous tubules of each type of spermatogenic cell.

\section{Sperm examination}

The distal portion of the right caudal epididymis was dissected, weighed, placed in the medium (37 C, Hank's solution containing 0.5\% BSA [8]) and allowed to disperse. After several minutes, a small amount of sperm suspension was collected and prepared for sperm morphological examination. The caudal epididymis was then minced in medium, incubated for more than $1 \mathrm{hr}$ at $37 \mathrm{C}$ and filtrated through nylon mesh for debris removal. The sperm suspension was counted under a microscope for the calculation of sperm per weight of caudal epididymis.

The sperm suspension collected for the morphological examination was stained with $0.5 \%$ Eosin Y, smeared onto a slide glass, air-dried overnight, fixed in methanol and examined microscopically [3]. Two hundred spermatozoa in each sample were examined for head, neck and tail morphological abnormalities [14]. For the classification of sperm morphological abnormalities, Yoshizaki's classification [9] was slightly modified and classified as follows: 1) tailless sperm, 2) no-hook head sperm, 3) amorphous head sperm, 4) sperm with neck abnormalities, 5) sperm with tail abnormalities, and 6) other abnormal sperm.

Table 1. Reproductive organ weight and sperm data

\begin{tabular}{|c|c|c|c|c|c|c|c|c|}
\hline \multirow{2}{*}{$\begin{array}{l}\text { Recovery } \\
\text { period } \\
\text { / Dose }\end{array}$} & \multirow{2}{*}{$\begin{array}{l}\text { No. of } \\
\text { animals }\end{array}$} & \multirow{2}{*}{$\begin{array}{l}\text { Final body } \\
\text { weight }(\mathrm{g})\end{array}$} & \multicolumn{2}{|c|}{ Testes } & \multicolumn{2}{|c|}{ Epididymides } & \multirow{2}{*}{$\begin{array}{l}\text { No. of } \\
\text { sperm }^{3)}\end{array}$} & \multirow{2}{*}{$\begin{array}{c}\text { Morphologically } \\
\text { abnormal } \\
\text { sperm }^{4)} \\
\end{array}$} \\
\hline & & & Absolute $^{1)}$ & Relative $^{2)}$ & Absolute $^{1)}$ & Relative $^{2)}$ & & \\
\hline \multicolumn{9}{|l|}{ Day 1} \\
\hline Control & 5 & $424.1 \pm 9.0$ & $3.30 \pm 0.18$ & $7.79 \pm 0.30$ & $1.10 \pm 0.08$ & $2.58 \pm 0.17$ & $702.6 \pm 211.0$ & $2.7 \pm 1.5$ \\
\hline MMS $40 \mathrm{mg} / \mathrm{kg}$ & 5 & $401.1 \pm 11.1^{* *}$ & $3.20 \pm 0.45$ & $7.99 \pm 1.21$ & $0.98 \pm 0.14$ & $2.44 \pm 0.37$ & $578.9 \pm 141.6$ & $4.3 \pm 5.3$ \\
\hline \multicolumn{9}{|l|}{ Week 1} \\
\hline Control & 5 & $436.1 \pm 19.2$ & $3.22 \pm 0.27$ & $7.41 \pm 0.83$ & $1.03 \pm 0.07$ & $2.37 \pm 0.17$ & $596.2 \pm 119.5$ & $2.8 \pm 1.8$ \\
\hline MMS $40 \mathrm{mg} / \mathrm{kg}$ & 5 & $433.5 \pm 32.5$ & $3.29 \pm 0.23$ & $7.60 \pm 0.46$ & $1.00 \pm 0.03$ & $2.31 \pm 0.14$ & $644.8 \pm 123.4$ & $4.5 \pm 1.5$ \\
\hline \multicolumn{9}{|l|}{ Week 2} \\
\hline Control & 5 & $470.9 \pm 26.2$ & $3.19 \pm 0.21$ & $6.80 \pm 0.70$ & $1.11 \pm 0.09$ & $2.36 \pm 0.24$ & $657.4 \pm 99.6$ & $4.1 \pm 3.4$ \\
\hline MMS $40 \mathrm{mg} / \mathrm{kg}$ & 5 & $443.5 \pm 22.8$ & $3.25 \pm 0.19$ & $7.33 \pm 0.33$ & $1.02 \pm 0.08$ & $2.31 \pm 0.13$ & $589.9 \pm 70.6$ & $4.4 \pm 2.9$ \\
\hline \multicolumn{9}{|l|}{ Week 3} \\
\hline Control & 5 & $490.0 \pm 30.9$ & $3.08 \pm 0.31$ & $6.29 \pm 0.63$ & $1.11 \pm 0.13$ & $2.28 \pm 0.28$ & $759.0 \pm 152.7$ & $1.4 \pm 0.7$ \\
\hline MMS $40 \mathrm{mg} / \mathrm{kg}$ & 5 & $478.1 \pm 16.3$ & $3.29 \pm 0.56$ & $6.89 \pm 1.16$ & $1.07 \pm 0.13$ & $2.24 \pm 0.25$ & $546.1 \pm 133.9$ & $24.0 \pm 29.9$ \\
\hline \multicolumn{9}{|l|}{ Week 4} \\
\hline Control & 5 & $520.5 \pm 37.1$ & $3.53 \pm 0.18$ & $6.81 \pm 0.56$ & $1.18 \pm 0.05$ & $2.27 \pm 0.21$ & $765.2 \pm 127.7$ & $3.6 \pm 3.2$ \\
\hline MMS $40 \mathrm{mg} / \mathrm{kg}$ & 5 & $497.0 \pm 30.4$ & $3.30 \pm 0.13$ & $6.67 \pm 0.49$ & $1.09 \pm 0.04^{*}$ & $2.20 \pm 0.18$ & $462.3 \pm 180.9^{*}$ & $43.3 \pm 31.9^{*}$ \\
\hline \multicolumn{9}{|l|}{ Week 5} \\
\hline Control & 5 & $515.1 \pm 30.5$ & $3.57 \pm 0.36$ & $6.94 \pm 0.53$ & $1.23 \pm 0.13$ & $2.39 \pm 0.25$ & $832.6 \pm 106.5$ & $1.6 \pm 0.8$ \\
\hline MMS $40 \mathrm{mg} / \mathrm{kg}$ & 5 & $520.6 \pm 45.2$ & $3.26 \pm 0.24$ & $6.31 \pm 0.77$ & $1.09 \pm 0.10$ & $2.10 \pm 0.25$ & $469.9 \pm 161.5^{* *}$ & * $15.3 \pm 7.0^{*}$ \\
\hline
\end{tabular}

Data shown as mean \pm S.D.

1)Unnit: $g$

2)Each value is expressd as a permillage of final body weight.

3)Data shown as mean number of sperm $\left(\times 10^{6}\right)$ per $1 \mathrm{~g}$ cauda epididymis \pm S.D.

4)Data shown as percent morphologically abnormal in 200 sperm \pm S.D.

*: Significant difference from control $(\mathrm{P}<0.05)$.

**: Significant difference from control $(\mathrm{P}<0.01)$. 


\section{Statistical analysis}

Data were statistically analyzed as follows. Homogeneity of variance between the groups was tested using the F-test [10]. With homogenous data, Student's $t$-test [10] was used. When variance was not homogenous, the Aspin-Welch method [10] was employed. Probabilities less than 5\% were considered statistically significant.

\section{Results}

Clinical signs, body weights, organ weights and sperm parameters

No severe clinical signs, such as deaths or moribund animals were observed during the study period. There was a slight but statistically significant decrease in body weight in the MMStreated group on Day 1. No significant decreases in the relative weights of testes or epididymides were observed during the observation period. The numbers of sperm in the cauda epididymis were significantly decreased in Week 4 and Week 5 . The frequency of morphologically abnormal sperm in the cauda epididymis increased between Week 3 and Week 5. The peak severity of the effect was observed in Week 4, in which the difference from the control was statistically significant. A significant difference from control was also observed in Week 5 (Table 1). The details of morphologically abnormal sperm in the cauda epididymis are listed in Table 2. Statistically significantly increased frequencies of tailless sperm and no hook head sperm compared to the control were observed in Week 5 . The most frequently observed abnormalities in the cauda epididymis were tailless sperm and no-hook head sperm regardless of the recovery period.

\section{Histopathology and quantitative evaluation of spermatogenic cells}

Histopathological findings are recorded in Table 3. The grades of all the findings observed in the current study were up to "slight". In the MMStreated group, high frequencies of retention of step 19 spermatids at stage IX were observed from Day 1 through Week 3 (Fig. 1A). Necroses of germ cells were observed frequently in Week 1 and less

Table 2. Content of morphologically abnormal sperm

\begin{tabular}{|c|c|c|c|c|c|c|c|}
\hline $\begin{array}{l}\text { Recovery } \\
\text { period } \\
\text { / Dose }\end{array}$ & $\begin{array}{c}\text { No. of } \\
\text { animals }\end{array}$ & Tailless & $\begin{array}{l}\text { No hook } \\
\text { head }\end{array}$ & $\begin{array}{c}\text { Amorphous } \\
\text { head }\end{array}$ & $\begin{array}{c}\text { Neck } \\
\text { abnormalities }\end{array}$ & $\begin{array}{c}\text { Tail } \\
\text { abnormalities }\end{array}$ & $\begin{array}{c}\text { Other } \\
\text { abnormalities }\end{array}$ \\
\hline \multicolumn{8}{|l|}{ Day 1} \\
\hline Control & 5 & $1.5 \pm 1.4$ & $0.6 \pm 0.5$ & $0.2 \pm 0.3$ & $0.1 \pm 0.2$ & $0.4 \pm 0.7$ & $0.0 \pm 0.0$ \\
\hline MMS $40 \mathrm{mg} / \mathrm{kg}$ & 5 & $3.5 \pm 4.8$ & $0.1 \pm 0.2$ & $0.1 \pm 0.2$ & $0.0 \pm 0.0$ & $0.6 \pm 0.7$ & $0.0 \pm 0.0$ \\
\hline \multicolumn{8}{|l|}{ Week 1} \\
\hline Control & 5 & $1.9 \pm 1.5$ & $0.6 \pm 0.5$ & $0.1 \pm 0.2$ & $0.3 \pm 0.4$ & $0.0 \pm 0.0$ & $0.0 \pm 0.0$ \\
\hline MMS $40 \mathrm{mg} / \mathrm{kg}$ & 5 & $3.0 \pm 2.3$ & $0.9 \pm 1.0$ & $0.3 \pm 0.3$ & $0.2 \pm 0.4$ & $0.2 \pm 0.3$ & $0.0 \pm 0.0$ \\
\hline \multicolumn{8}{|l|}{ Week 2} \\
\hline Control & 5 & $2.7 \pm 2.5$ & $0.1 \pm 0.2$ & $0.2 \pm 0.3$ & $0.2 \pm 0.3$ & $1.0 \pm 1.2$ & $0.0 \pm 0.0$ \\
\hline MMS $40 \mathrm{mg} / \mathrm{kg}$ & 5 & $4.0 \pm 2.9$ & $0.2 \pm 0.3$ & $0.0 \pm 0.0$ & $0.2 \pm 0.3$ & $0.0 \pm 0.0$ & $0.0 \pm 0.0$ \\
\hline \multicolumn{8}{|l|}{ Week 3} \\
\hline Control & 5 & $0.5 \pm 0.6$ & $0.5 \pm 0.6$ & $0.1 \pm 0.2$ & $0.1 \pm 0.2$ & $0.2 \pm 0.3$ & $0.1 \pm 0.2$ \\
\hline MMS $40 \mathrm{mg} / \mathrm{kg}$ & 5 & $18.1 \pm 28.0$ & $1.7 \pm 1.5$ & $2.1 \pm 2.5$ & $0.6 \pm 1.1$ & $0.0 \pm 0.0$ & $1.5 \pm 2.8$ \\
\hline \multicolumn{8}{|l|}{ Week 4} \\
\hline Control & 5 & $1.8 \pm 1.9$ & $0.2 \pm 0.4$ & $0.6 \pm 0.5$ & $0.7 \pm 0.8$ & $0.4 \pm 0.4$ & $0.0 \pm 0.0$ \\
\hline MMS $40 \mathrm{mg} / \mathrm{kg}$ & 5 & $25.8 \pm 29.9$ & $7.6 \pm 8.2$ & $2.5 \pm 2.9$ & $4.8 \pm 3.7$ & $1.3 \pm 1.0$ & $3.1 \pm 5.4$ \\
\hline \multicolumn{8}{|l|}{ Week 5} \\
\hline Control & 5 & $1.0 \pm 0.4$ & $0.1 \pm 0.2$ & $0.2 \pm 0.4$ & $0.1 \pm 0.2$ & $0.2 \pm 0.3$ & $0.0 \pm 0.0$ \\
\hline MMS $40 \mathrm{mg} / \mathrm{kg}$ & 5 & $7.1 \pm 2.8^{* *}$ & $4.3 \pm 2.3^{*}$ & $1.1 \pm 1.9$ & $2.2 \pm 1.8$ & $1.1 \pm 1.7$ & $0.3 \pm 0.7$ \\
\hline
\end{tabular}

Data shown as mean \pm S.D.

*: Significant difference from control $(\mathrm{P}<0.05)$.

**: Significant difference from control $(\mathrm{P}<0.01)$. 
Table 3. Histopathological findings

\begin{tabular}{|c|c|c|c|c|c|c|c|c|c|c|}
\hline \multirow{2}{*}{$\begin{array}{l}\text { Recovery period/Dose } \\
\text { Findings / Grade }\end{array}$} & \multicolumn{5}{|c|}{ Control } & \multicolumn{5}{|c|}{ MMS $40 \mathrm{mg} / \mathrm{kg}$} \\
\hline & - & \pm & + & ++ & +++ & - & \pm & + & ++ & +++ \\
\hline \multicolumn{11}{|l|}{ Day 1} \\
\hline \multicolumn{11}{|l|}{ Testis } \\
\hline Atrophy of seminiferous tubules & 3 & 1 & 1 & & & 4 & & 1 & & \\
\hline Necrosis of germ cells & 5 & & & & & 3 & & 2 & & \\
\hline Retention of spermatids (elongate) ${ }^{\#}$ & 5 & & & & & 1 & 4 & & & \\
\hline Vacuolar degeneration of Sertoli cell & 5 & & & & & 4 & & 1 & & \\
\hline \multicolumn{11}{|l|}{ Epididymis } \\
\hline Spermatic granuloma & 5 & & & & & 4 & & 1 & & \\
\hline \multicolumn{11}{|l|}{ Week 1} \\
\hline \multicolumn{11}{|l|}{ Testis } \\
\hline Atrophy of seminiferous tubules & 5 & & & & & 3 & & 2 & & \\
\hline Necrosis of germ cells & 5 & & & & & & & 5 & & \\
\hline Retention of spermatids (elongate) ${ }^{\#}$ & 5 & & & & & 1 & 2 & 2 & & \\
\hline Vacuolar degeneration of Sertoli cell & 5 & & & & & 4 & & 1 & & \\
\hline \multicolumn{11}{|l|}{ Epididymis } \\
\hline * & 5 & & & & & 5 & & & & \\
\hline \multicolumn{11}{|l|}{ Week 2} \\
\hline \multicolumn{11}{|l|}{ Testis } \\
\hline Atrophy of seminiferous tubules & 4 & 1 & & & & 4 & 1 & & & \\
\hline Retention of spermatids (elongate) ${ }^{\#}$ & 5 & & & & & & & 5 & & \\
\hline Vacuolar degeneration of Sertoli cell & 5 & & & & & 3 & 1 & 1 & & \\
\hline \multicolumn{11}{|l|}{ Epididymis } \\
\hline Cell debris in epididymal ducts of caput & 5 & & & & & 4 & & 1 & & \\
\hline \multicolumn{11}{|l|}{ Week 3} \\
\hline \multicolumn{11}{|l|}{ Testis } \\
\hline Retention of spermatids (elongate) & 5 & & & & & 1 & 2 & 2 & & \\
\hline \multicolumn{11}{|l|}{ Epididymis } \\
\hline Cell debris in epididymal ducts of caput & 5 & & & & & 4 & & 1 & & \\
\hline \multicolumn{11}{|l|}{ Week 4} \\
\hline \multicolumn{11}{|l|}{ Testis } \\
\hline Atrophy of seminiferous tubules & 4 & & 1 & & & 4 & & 1 & & \\
\hline \multicolumn{11}{|l|}{ Epididymis } \\
\hline Cell debris in epididymal ducts of caput & 5 & & & & & 4 & & 1 & & \\
\hline Cell debris in epididymal ducts of cauda & 5 & & & & & 4 & & 1 & & \\
\hline \multicolumn{11}{|l|}{ Week 5} \\
\hline \multicolumn{11}{|l|}{ Testis } \\
\hline * & 5 & & & & & 5 & & & & \\
\hline \multicolumn{11}{|l|}{ Epididymis } \\
\hline * & 5 & & & & & 5 & & & & \\
\hline
\end{tabular}

-: Not remarkable, \pm : Very slight, +: Slight, ++: Moderate, +++: Marked. \#: Step 19 spermatids at stage IX.

*: No abnormal findings.

frequently on Day 1 (Fig.1B). Other findings such as vacuolar degeneration of Sertoli cells, atrophy of seminiferous tubules (Fig. 1C and D) and spermatic granuloma in epididymis were observed with very low frequency.

Quantitative evaluation of spermatogenic cells in seminiferous tubules revealed that the number of round spermatids in stage $\mathrm{V}$, spermatogonea in stage $\mathrm{X}$, zygotene spermatocytes in stage XII, and pachytene spermatocytes in stage XII in the MMStreated group were significantly lower than those of concurrent control on Day 1 (Figs. 2, 3). Statistically not significant, but substantially lower numbers of round spermatids were observed in stage II-III on Day 1. There were no significant differences from the control in the population of 

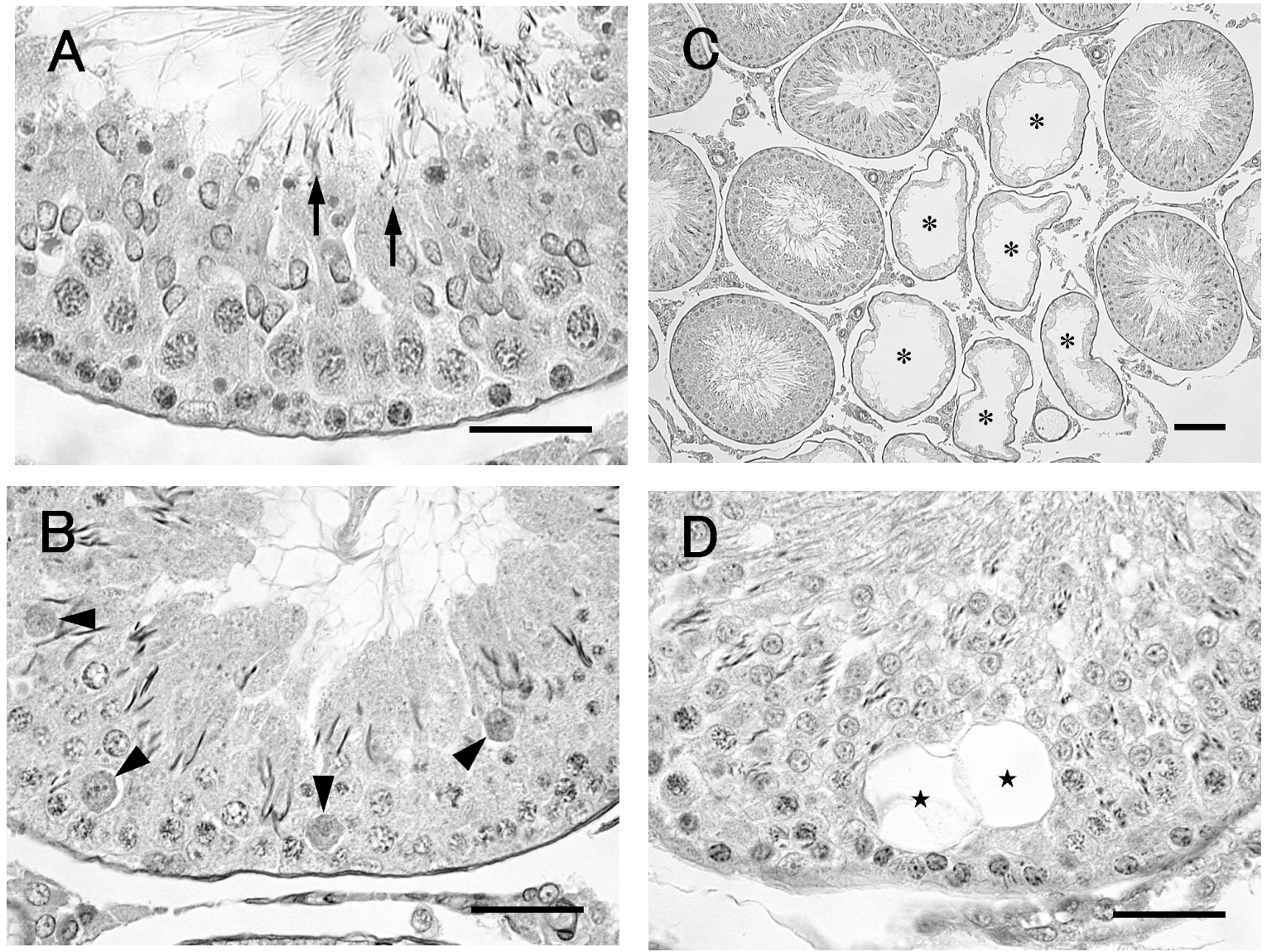

Fig. 1. Testes from rats treated with MMS at Week 1. A: A tubule of stage IX. Note retention of spermatids (arrows). B: A tubule of stage XIV. Note necrotic cells between germ cells (arrowheads). C: Note atrophic tubules with Sertoli cell only (asterisks). D: A tubule of stage II-III. Note vacuolated Sertoli cells (stars). Bars: A, B, D, 0.03 mm; C, 0.1 mm. PAS staining.

spermatogenic cells in Week 1.

Regarding evaluation of apoptosis, a significantly higher frequency of TUNEL positive seminiferous tubules was observed in stage XIV-I (meiosis stage spermatocytes) in Week 1 in the MMS-treated group (Fig. 4). No other differences were observed in the frequency of TUNEL positive cells in seminiferous tubules when compared with the control (Fig. 5).

\section{Discussion}

It has been reported that MMS causes a decrease in testes and epididymes weight, as well as a decrease of germ cells, exfoliation of germ cells and vacuolar degeneration of Sertoli cells after oral treatment of $40 \mathrm{mg} / \mathrm{kg}$ for 2 weeks [1].
In the present study, findings observed in the previous study [1], such as decreased weight of testis and epididymes and decreased germ cells and exfoliation of germ cells, were not observed. These differences in findings might be due to differences in duration of dosing from the previous study. In the present study, however, we have successfully demonstrated an increase of morphologically abnormal sperm in the cauda epididymis.

Quantitative evaluation of spermatogenic cells in seminiferous tubules revealed that the number of spermatogonea and stage XII zygotene spermatocytes were significantly decreased on Day 1. Spermatogonia are the major proliferative cells of the testes. Spermatogonia are the primary target for alkylating agents such as Cyclophosphamide, because of their high mitotic activity [11]. A 
Stage II-III
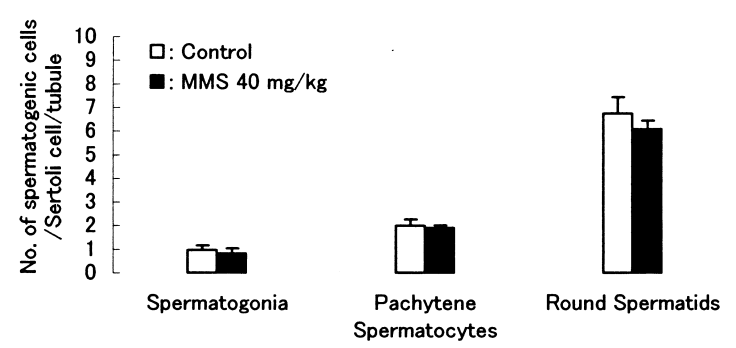

Stage VII

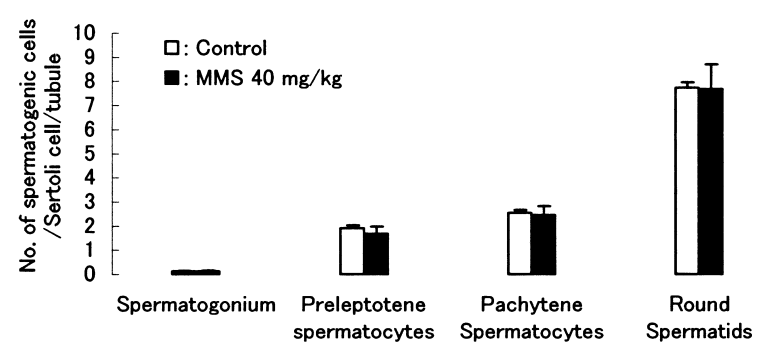

Stage XII
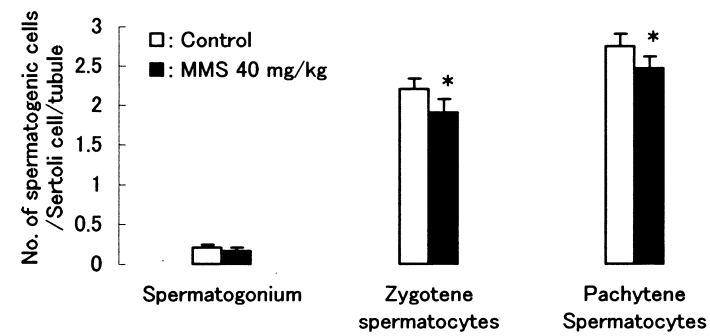

Stage V

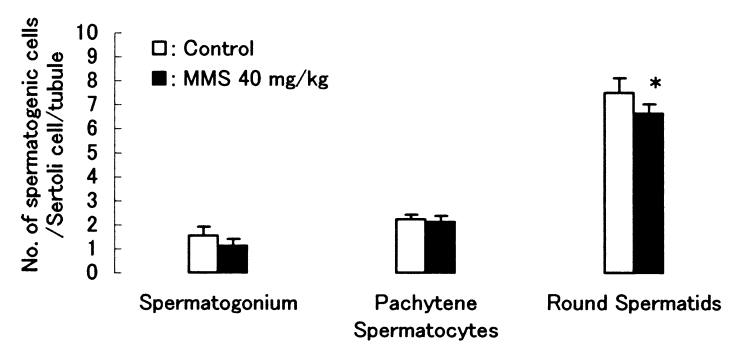

Stage $X$

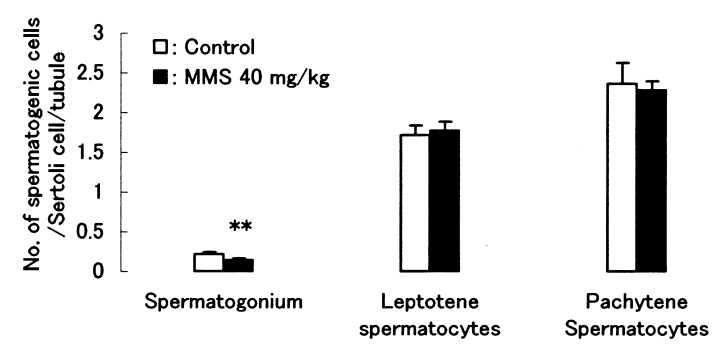

Fig. 2. Quantitative evaluation of spermatogenic cells on Day 1. *: Significant difference from control $(\mathrm{P}<0.05)$. $* *$ : Significant difference from control $(\mathrm{P}<0.01)$.

decreased number of cells in stage XII zygotene seems to reflect the effect of MMS on preleptotene spermatocytes in which final DNA synthesis is performed at the onset of meiosis. In the current study, there was a consistent decrease in the number of late pachytene spermatocytes and early spermatids in the MMS-treated group on Day 1. These findings indicate a loss of germ cells in this period and subsequently a decreased number of spermatozoa in the caudal epididymes in Week 4 and Week 5. A previous report indicated that unscheduled DNA synthesis (UDS), an indirect measure of DNA lesions, after MMS treatment takes place in the germ cells in stages from the leptotene to mid spermatid in mice [5]. Thus, the decreased numbers of cells in late spermatocytes and early spermatids in the present study may be related to the effect of genetic damage in these cells.
One of the causes of morphological abnormalities in spermatozoa is also thought to be the DNA insult of germ cells $[4,5]$. In the current study, morphologically abnormal spermatozoa increased from Week 3 and the increased values lasted until Week 5. The presumable exposure periods of germ cells in these recovery periods were stages from the leptotene to mid spermatid in the current study (total transit time for spermatozoa from the initial caput segment to cauda epididymis was considered to be 8 days [12]) which was completely consistent with the UDS observed in mice. Furthermore, peak severity in the frequency of morphologically abnormal spermatozoa was observed in Week 4, in which germ cells were assumed to be exposed to MMS during the period of late pachytene spermatocytes and early spermatids. These periods are in agreement with the period in which 
Stage II-III

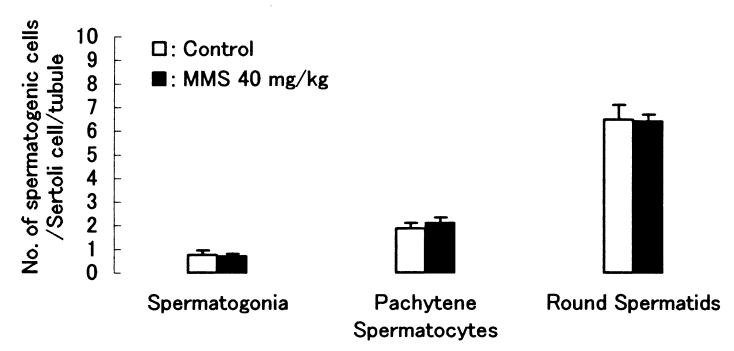

Stage VII

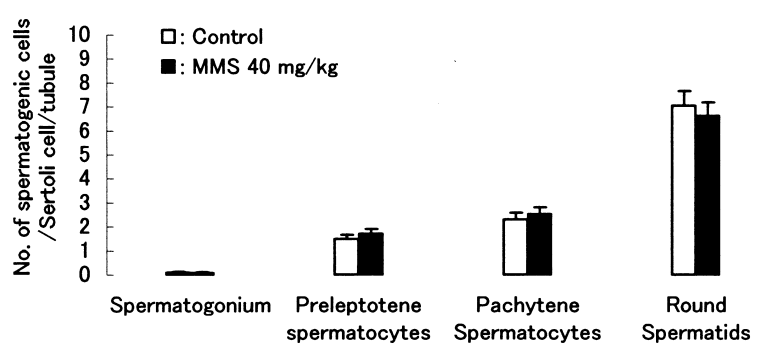

Stage XII

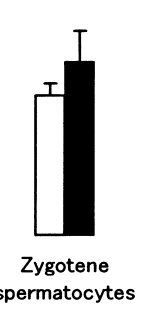

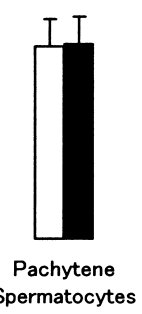

Fig. 3. Quantitative evaluation of spermatogenic cells in Week 1 .
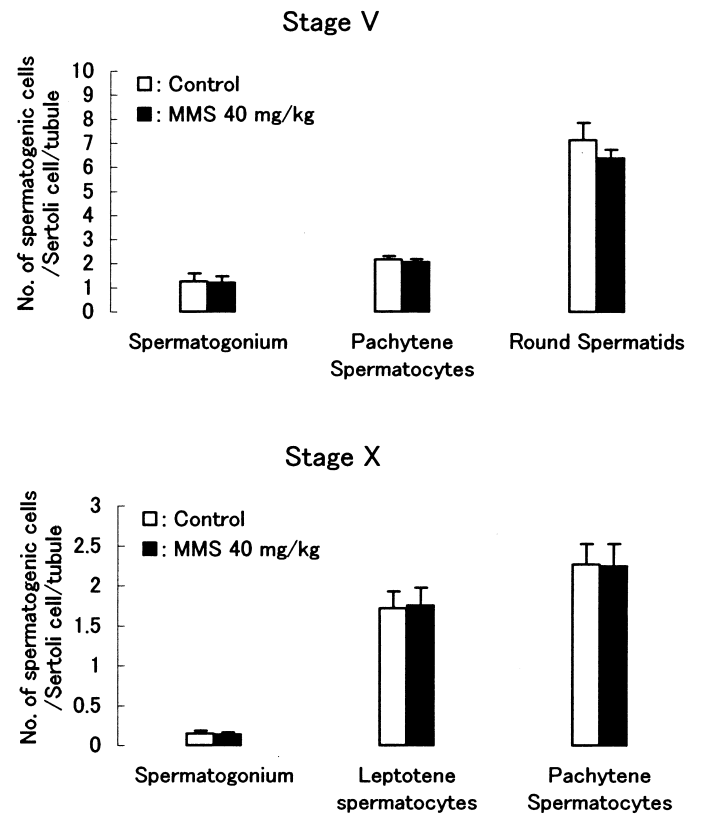

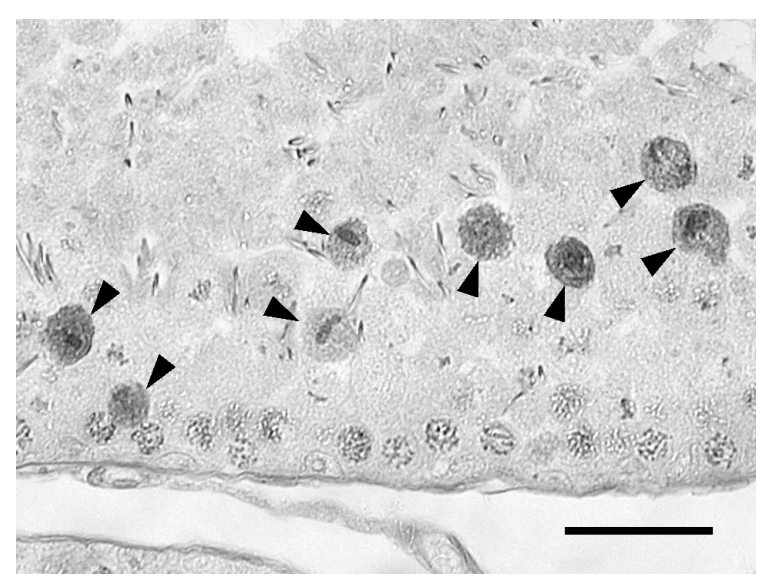

Fig. 4. TUNEL staining of testis of a rat treated with MMS at Week 1 . TUNEL positive cells were frequently observed in tubules of stage XIV (arrowheads). Bar: $0.03 \mathrm{~mm}$. decreased spermatogenic cells were detected in the morphometry analysis on Day 1 . These consistencies seem to indicate the susceptibility to genetic insult of rat spermatogenic cells in those stages.

In the TUNEL examination, a significantly high frequency of apoptosis was observed in the meiosis cells in Week 1 for the cells exposed to MMS during stages I to VII of the spermatocyte. The presumed period of the MMS exposure in Week 5 spermatozoa, in which morphologically abnormal spermatozoa were decreased, is the period during stages IV to VII of the spermatocyte. This seems to indicate that some of the genetically insulted cells, which had been exposed to MMS up to stage VII and before with the potential to express morphological abnormalities in spermatozoa, are eliminated in the process of apoptosis during meiosis; and this in turn decreased the number of 
Day 1

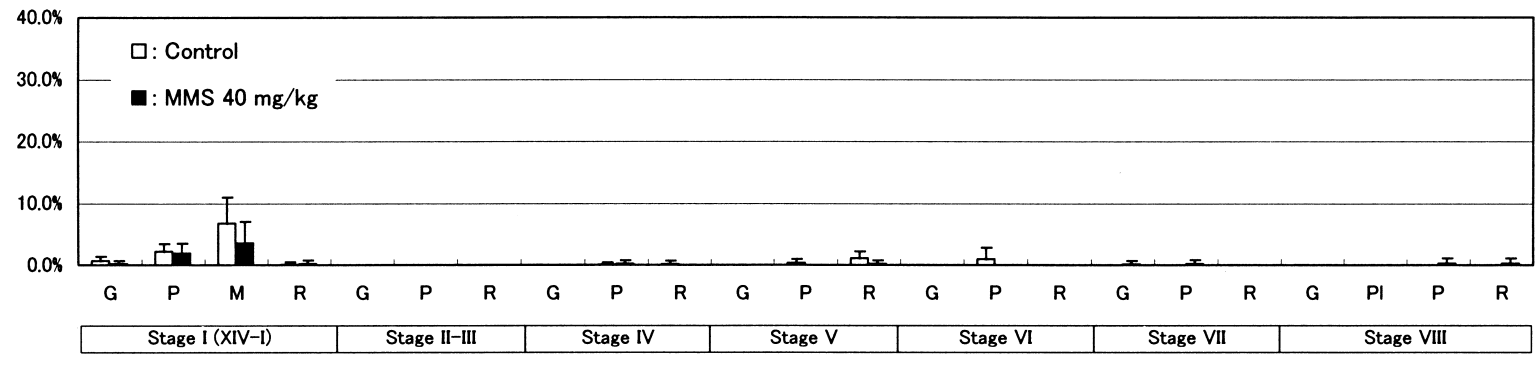

Day 1

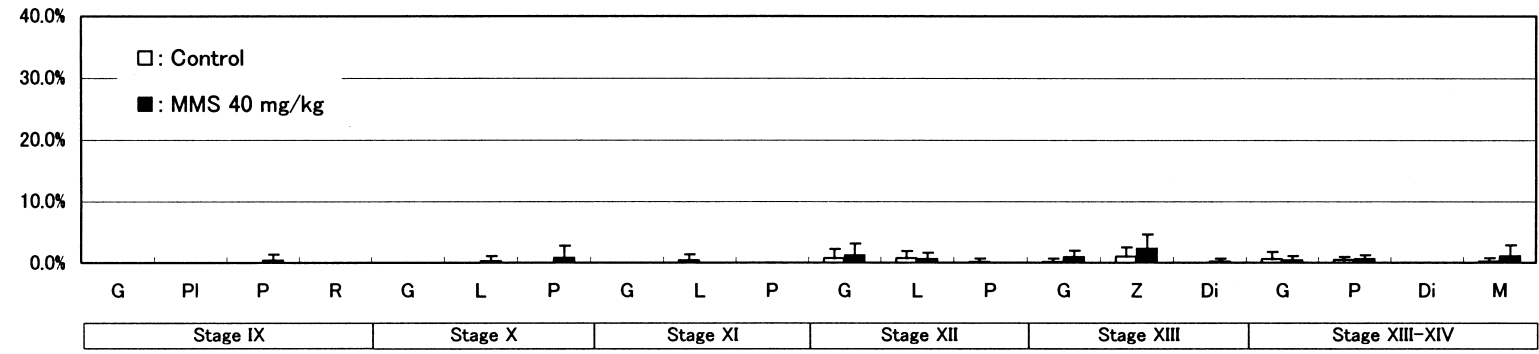

Week 1

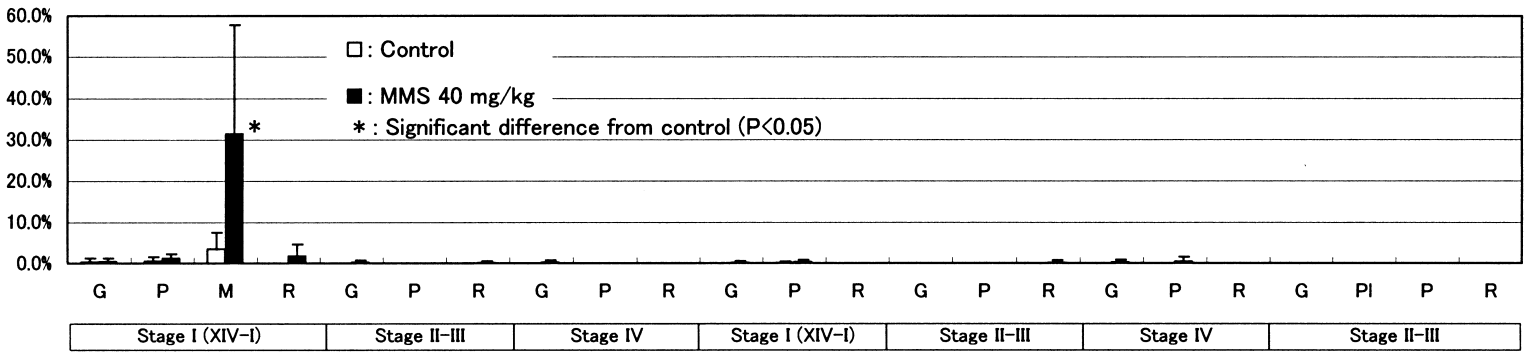

Week 1

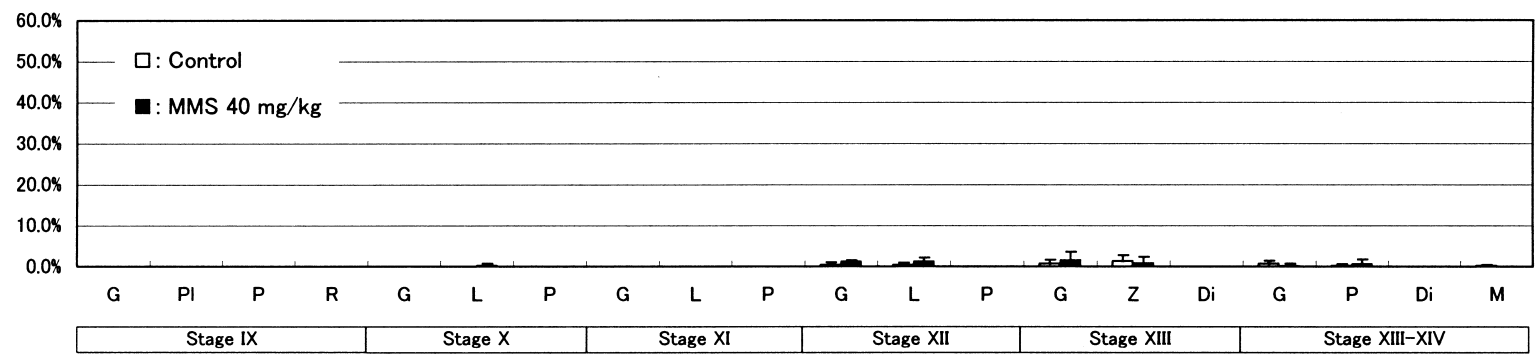

Fig. 5. Frequency of apoptosis detected cells. G: spermatogonium, P: pachytene spermatocytes, M: meiosis spermatocytes, $\mathrm{R}$ : round spermatocytes, Pl: preleptotene spermatocytes, L: leptotene spermatocytes, Z: zygotene spermatocytes, Di: diplotene spermatocytes, ${ }^{*}$ : Significant difference from control $(\mathrm{p}<0.05)$.

morphologically abnormal spermatozoa in Week 5 . Accumulation of DNA insult during sperm maturation, the so-called "storage effect", has been reported in mice [5]. Genetically insulted spermatogenic cells, exposed to MMS from stage
XII pachytene to stage I spermatid, but not discriminated in the process of meiosis, exhibited the highest frequency of morphological abnormalities in Week 4. A reduced frequency of morphologically abnormal spermatozoa in Week 3 
may have been due to shorter latency in the reproductive tract before examination. In the present study, there was no increase in the frequency of morphologically abnormal spermatozoa between Day 1 and Week 2, in which spermatogenic cells were exposed to MMS during the stage of the late spermatid to spermatozoa. Lack of morphologically abnormal spermatozoa does not indicate a lack of genetic damage in spermatogenic cells. Susceptibility of genetic insult in the late spermatid and early spermatozoa after MMS exposure has been reported in mice and rats. In mice, MMS treatment in this stage has been reported to induce DNA single-strand breaks in germ cells [5]. In rats, MMS exposed germ cells in this stage induced dominant lethals at mating [13]. Mechanisms of morphological alterations in sperm shape, or disruption of the differentiation of spermatozoa, after DNA insult have not been fully investigated; however, the outcome of accumulated insults to DNA after the "storage effect" would be expressed as delayed spermiation, altered function of cells, or cell death, ultimately. In the present study, a majority of the morphologically abnormal spermatozoa observed were tailless sperm, followed by no-hook head sperm. Thus, the alteration in the shape of spermatozoa detected in the current study may simply represent degenerated spermatozoa in the reproductive tract.

Retention of step 19 spermatids at stage IX was observed from Day 1 to Week 3 in the current study. This finding was consistent with the result of 2 weeks treatment with MMS at $40 \mathrm{mg} / \mathrm{kg}$ in rats [1]. This finding is thought to be the release failure of spermatids from Sertoli cells, and a close relationship with morphologically abnormal sperm is also reported for boric acid [14], dibromoacetic acid [15] and valproic acid [16]. Several mechanisms could be the cause of this finding [1518]. They are mainly hormonal disruption in testis, and Sertoli cell and/or spermatid dysfunctions. Hormonal disruption in the rat testis usually involves degeneration of mid-pachytene spermatocytes and Step 7 spermatids in stage VII [19], but none of these changes were detected in the histopathological examination. Vacuolization of Sertoli cells, which can be related to Sertoli cell dysfunction, and was consistently observed in the 2 weeks treatment study [1], was only observed with a low frequency in the current study. Other findings associated with Sertoli cell dysfunction, such as atypical residual bodies in the lumen [14] were not detected in the histopathological examination. Assuming the cause of retention to be the altered function of the spermatid, accumulated insults to DNA in spermatogenic cell could delay the maturation of spermatids and/or be expressed as altered function in spermatids. Furthermore, complete loss of retention in Week 4 and later was in agreement with discrimination of genetically damaged cells by apoptosis in the course of meiosis. Further investigations will be needed to clarify the mechanism; however, genetic insults may be deeply associated with the cause retention.

In the present study, genetic damage induced by the treatment of MMS affected a wide variety of spermatogenic cells in testis, and changes were exhibited such as a decrease in the number of germ cells per Sertoli cell from the late spermatocyte to early spermatid, retention of step 19 spermatid, an increased frequency of morphologically abnormal spermatozoa and a decreased number of sperm in the caudal epididymis. Apoptosis in the course of meiosis seems to be involved in the elimination process of genetically insulted germ cells, and this process seems to play an important role in eliminating and/or decreasing the germ cells with the potential to express retention of spermatids and morphologically abnormal spermatozoa.

\section{References}

1. Ozawa S, Yokoi R, Kitamura T, Kuriyama K, Kobayashi K, Shibata N. Collaborative work to evaluate toxicity on male reproductive organs by repeated dose studies in rats 15). Two-week and 4week administration study of methyl methanesulfonate (MMS). J Toxicol Sci 2000; 25: 155162.
2. Cassidy SL, Dix KM, Jenkins T. Evaluation of a testicular sperm head counting technique using rats exposed to dimethoxyethyl phthalate (DMEP), glycerol alpha-monochlorohydrin (GMCH), epichlorohydrin (ECH), formaldehyde (FA), or methyl methanesulphonate (MMS). Arch Toxicol 1983; 53: 71-78. 
3. Wyrobek AJ, Bruce WR. Chemical induction of sperm abnormalities in mice. Proc Natl Acad Sci U S A 1975; 72: 4425-4429.

4. Bruce WR, Heddle JA. The mutagenic activity of 61 agents as determined by the micronucleus, salmonella, and sperm abnormality assays. Can J Genet Cytol 1979; 21: 319-334.

5. Inoue $\mathbf{M}$, Kurihara $\mathbf{T}$, Yamashita $\mathbf{M}$, Tatsumi K. Effects of treatment with methyl methanesulfonate during meiotic and postmeiotic stages and maturation of spermatozoa in mice. Mutat Res 1993; 294: 179-186.

6. Kuze T. Comparison of various fixatives on rat testis. Jpn J Histotech 1997; 6: 17-22.

7. Matsui H, Toyoda K, Kawanishi T, Mitsumori K, Takahashi M. Advantages of simplified quantitative morphometry using stage grouping analysis of spermatogenic cycle for evaluation of the testicular toxicity of Ethylene-1,2dimethanesulfonate in rats. J Toxicol Pathol 1996; 9: 285-292.

8. Klinefelter GR, Gray LE Jr, Suarez JD. The method of sperm collection significantly influences sperm motion parameters following ethane dimethanesulphonate administration in the rat. Reprod Toxicol 1991; 5: 39-44.

9. Yoshizaki H, Izumi Y, Hirayama C, Fujimoto A, Kandori H, Sugitani T, Ooshima Y. Availability of sperm examination for male reproductive toxicities in rats treated with boric acid. J Toxicol Sci 1999; 24: 199-208.

10. Yoshimura I. In "Statistical Analysis of Toxicity and Drug Efficacy Data". Tokyo Scientist Inc., 1987: 2840 (in Japanese).

11. Higuchi H, Nakaoka M, Ozaki K, Kawamura S,
Okuno Y, Matsuo M, Yasuhara K. Evaluation of recovery from cyclophosphamide testicular toxicity in rats. J Toxicol Pathol 1997; 10: 165-173.

12. Sujarit S, Pholpramool C. Enhancement of sperm transport through the rat epididymis after castration. J Reprod Fertil 1985; 74: 497-502.

13. Ashby J, Lefevre PA, Elliott BM, Clapp MJ. Methyl methanesulphonate (MMS) as a resource conserving and reliable positive control agent for male rat and male mouse dominant lethal assays. Mutagenesis 1996; 11: 611-613.

14. Linder RE, Strader LF, Slott VL Suarez JD. Endpoints of spermatotoxicity in the rat after short duration exposures to fourteen reproductive toxicants. Reprod Toxicol 1992; 6: 491-505.

15. Linder RE, Klinefelter GR, Strader LF, Suarez JD, Roberts NL, Dyer CJ. Spermatotoxicity of dibromoacetic acid in rats after 14 daily exposures. Reprod Toxicol 1994; 8: 251-259.

16. Nishimura T, Sakai $\mathbf{M}$, Yonezawa $\mathbf{H}$. Effects of valproic acid on fertility and reproductive organs in male rats. J Toxicol Sci 2000; 25: 85-93.

17. Tsuchiya T, Sano F, Oikawa N, Goto K, Sugimoto J, Mutai M. Development of Ethinylestradiol (EE)induced testicular atrophy in rats: Involvement of apoptosis in EE-induced spermatogenic cell death. $J$ Toxicol Sci 1996; 9: 359-368.

18. Matsumoto K, Matsumoto S, Yoshida T, Ooshima Y. Sperm abnormalities and histopathological changes in the testes in Cri:CD(SD)IGS rats. J Toxicol Sci 1999; 4: 63-68.

19. Russell LD, Malone JP, Karpas SL. Morphological pattern elicited by agents affecting spermatogenesis by stimulation. Tissue Cell 1981; 13: 369-380. 